\title{
15
}

\section{Kuriose Artnamen 2 (Hälftenrätsel)}

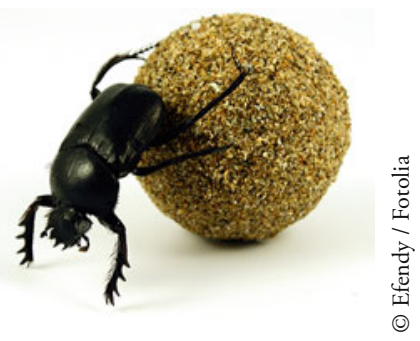

Kaum zu glauben, mit welchem Namen so manches Lebewesen ausgestattet ist! Kombiniere je zwei Türklingel-Hälften miteinander und finde heraus, wie diese Tiere heißen. Gut, in Wirklichkeit haben sie wohl keine Haustüren, die Lebewesen selbst gibt es aber. :)

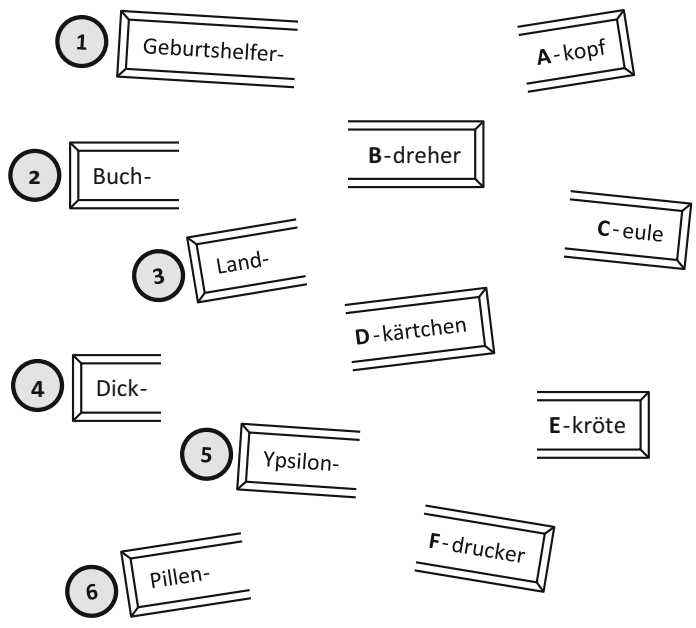

1.

2.

3.

Du kennst weitere kuriose Tier- und Pflanzennamen? Her damit! Schicke sie uns gerne an springerraetsel@yahoo.com.

(C) Springer-Verlag Berlin Heidelberg 2016

. 